\title{
Post-partition Citizenship Policies: Lessons from Post-Yugoslav Federal States
}

\author{
Jelena Džankić ${ }^{1}$ and Soeren Keil ${ }^{2}$
}

\begin{abstract}
Citizenship policies are important tools of inclusion and exclusion in a post-partition context. In most cases, they reflect the unitary and mono-ethnic character of the newly established states. Their function in states and territories where an ethnonational breakup resulted in further ethnically diverse societies is far more complex. Citizenship in multilevel states created through state disintegration is a counterintuitive combination of (1) the legacies of the old citizenship tradition and replications of the old federal structure, and (2) processes of ethnic engineering and designing group-centric citizenship regimes. Legacies of the old structure are framed by the modalities of breakup and initial determination of citizenry (e.g. the absence of zero solution), but strongly mirror elements of the previous multilevel construction of citizenship, including bottom-up derivation, ethno-national determination of membership, voting rights and representation. Discontinuities in citizenship policies reflect wider tensions between nation- and state-building (and destruction), and how these processes have been molded through different international influences. We engage in a case-study of two post-Yugoslav multilevel states, namely Bosnia and Herzegovina and the Federal Republic of Yugoslavia/the State Union of Serbia and Montenegro, but draw broader conclusions on how citizenship policies can keep states together or break them apart.
\end{abstract}

\section{Introduction}

The basic idea of any federal political system is the combination of unity and diversity, through the implementation of self-rule and shared-rule (Watts 1999, Elazar 1982, Burgess 2006). This core principle of federalism is strongly visible in citizenship policies within federal countries (Choudhry 2001). Questions such as 'who belongs' and who does not, and 'who gets what rights' lay at the heart of any state. They are the lifeblood of federal structures, often created by different groups coming together for defense and economic purposes (Riker 1964). In the words of Kenneth Wheare (1964), federalism is the outcome of deep-rooted diversity within a state. Manifold ethnic,

\footnotetext{
${ }^{1}$ European University Institute, Italy.

${ }^{2}$ Canterbury Christ Church University, UK.
} 
religious, linguistic, economic and political perspectives amongst people(s) within a state are then articulated through levels of government with different competences. This also has a substantial impact on citizenship policies, not only because these define 'who belongs', but also because they shape the wider relationship between an individual and the layers of territorial governance through a system of membership rights and obligations (Ferrera 2003).

Multinational federations are characterized by the existence of two or more separate national identities, which consider the joint state as their historical homeland, and which have a claim to participation and active recognition in the state (Requejo 1999, 2005; Norman 2006). Since federalism is one tool to manage this diversity through the provision of territorial autonomy and the protection of distinct identities, many multinational federal systems have developed citizenship legislation that reflects this diversity (Aron and Hofstadter 1974). As a result, even though systems of two-tiered citizenship are common in multinational federal countries, there is great variation in how federations across the world constitute their citizenship regimes and shape the relationship between the different tiers of governance. In countries such as India or Russia, only the federal government has the power to decide 'who belongs', and what rights and obligations their respective citizens have. In countries such as Austria, Belgium, Canada or Germany, territorial units have some competences in defining, awarding and implementing citizenship; in Switzerland, cantonal or communal citizenship is a prerequisite for the Swiss citizenship. The latter is also the case in the European Union (EU). Even though the EU is short of being a federal system, the supranational European citizenship is conditional upon citizenship of a Member State. The variation in how federations define whom they recognize as members will then also be reflected in the distribution of citizenship rights and obligations at different levels. For instance, subnational citizenship might affect one's taxation rates (Rosen 2002); both federal and subnational citizenship may impact on one's electoral rights (Schmid, Piccoli \& Arrighi 2019).

A particular kind of federal states, and a rather uncommon one, are those created through the collapse of multinational federations. State disintegration normally results in unitary states, because nationalist dynamics of matching national and territorial boundaries aim at creating more homogenous states. Yet, as both the Yugoslav and the Soviet disintegration highlight, ethno-territorial break-ups like all forms of secession, 
do not solve the issues of ethnic and cultural plurality (Heinemann-Grüder 2002, Grgić 2017). Instead, they create new forms of diversity and potential conflict (Horowitz 2003). Hence, while there are only a small number of post-partition federations (Bosnia and Herzegovina, the Federal Republic of Yugoslavia and Russia are the most prominent examples here), our discussion on the former Yugoslav republics is nonetheless relevant for other potentially secessionist territories, in which diversity accommodation takes place through territorial autonomy (e.g., Spain, the UK, Canada). The break-up of the socialist Yugoslavia (SFRY) (1946-1991) had, at different points and for different reasons, resulted in the creation of two post-partition multinational federal states - the Federal Republic of Yugoslavia (FRY) (1992-2002) and Bosnia and Herzegovina $(\mathrm{BiH})$ - in addition to several unitary countries. The federal state that Serbia and Montenegro established in 1992, progressively weakened. It was transformed into the State Union Serbia and Montenegro (2003-2006) and disappeared completely with the independence of Montenegro in 2006. In the FRY, the two-tiered citizenship regime resulted out of the constitutional setup of the federation. In the case of $\mathrm{BiH}$, international intervention played a major role in holding the multinational state together and set the parameters for regulating inclusion and exclusion of citizens at different levels within the state.

Both post-partition federations have had the same previous experience of a multi-level citizenship regime in the socialist Yugoslavia. The federal citizenship legislation provided the framework for republican laws, but the republics as constituent units were responsible for the actual guarantee of citizenship rights. In this regard, Yugoslavia was not substantially different from other federal states, including the US. The FRY and $\mathrm{BiH}$ adapted and followed the principles of socialist Yugoslavia in their citizenship legislation. Yet, the conflicts of the early 1990s, the modalities of break-up, and the subsequent processes of state- and nation-building, have all had a strong and distinct impact on the new states' citizenship regimes. The effects of the interplay of these different dynamics can best be seen in the political-legal dimension of citizenship, which deals questions of formal membership and the associated rights; and in its normative-psychological dimension, where citizenship can be a tool for defining belonging in diverse societies through inclusion, openness, tolerance and acceptance, or be a contrivance exclusion and ethnic engineering (Shaw and Štiks 2010, 12). Citizenship, therefore, can be inclusive by extending membership entitlements to 
different linguistic, religious and cultural groups, or exclude when coupled with ethnic identity and kinship as determinants of political entitlements.

Conceiving of our analysis through the lenses of historical institutionalism, ${ }^{\mathrm{i}}$ we use the FRY and $\mathrm{BiH}$ as examples of federal states created by different kinds of ethnonational break-ups to explore to what extent the citizenship structures of the old multi-level state have been reflected in the new ones, what other elements new citizenship policies contain and why. In so doing we first look at continuities, distinguishing between (1) the shared institutional legacies common to all post-Yugoslav states and (2) specific structural replications of the old federal structure in those territories where ethnonational break-up remained incomplete. We then explore discontinuities in citizenship policies as a reflection of wider tensions between the processes of nationand state-building (and destruction), as well as international influence in the Balkans.

We proceed by first setting the grounds for analysis by looking at the different aspects of citizenship in multilevel polities. Then we identify the potential historical continuities by tracing the evolution of the citizenship regime of socialist Yugoslavia. We subsequently focus on the citizenship regime in the FRY, the state that formed in 1992 as a union of Serbia and Montenegro amid the Yugoslav break-up. We follow by exploring the citizenship regime in Bosnia and Herzegovina, which has been heavily influenced not only by the results of the war (1992-1995), but also by external statebuilders. Beyond these specific cases, our Conclusions highlight that citizenship policies in new post-secession states will reflect the vestiges of previous citizenship regimes. These historical legacies, including multi-level citizenship regimes, will be mixed with new provisions reflecting state- and nation-building experiences of the postsecession states. In this framework, one can expect that any future state that becomes independent from a multi-level political system, will adjust its new citizenship regime both to the experiences and legacies of the past, as well as to the specific aims of those in charge of nation-building and state construction.

\section{Citizenship as Membership in National and Multilevel Polities: Legacies and}

\section{Linkages}

Being a relationship between an individual and the state, the notion of citizenship is both reciprocal and multivalent (Linklater 1996; Miller 2000). It is reciprocal because 
it includes a constant exchange in the form of rights and duties of membership. For giving legitimacy to governance by participating, individuals receive protection from the state's monopoly in the form of citizenship rights. In turn, they have the obligation to sustain and protect the state through the duties of citizenship such as taxation and law abidance. This reciprocity ensures the legitimate continuity of the state through the approval of citizens. The link represented by the notion of citizenship is also multivalent, as it includes not only matters of status and rights, but also those of belonging and loyalty. This latter dimension shapes the boundaries of citizenship because states adopt 'rules governing access to and control of scarce resources' (Shachar 2009, 32). Those rules are commonly based on the presumptions of belonging and loyalty and stipulated in laws regulating the status and rights of citizenship.

In other words, citizenship has multiple dimensions, commonly expressed as 'citizenship triads' (Schuck 2000; Joppke 2007; Bellamy 2004). First, it has a membership dimension constituted of the rules for inclusion and exclusion, based on the state and ethnic identities defined in the constitution. Second, citizenship has a political dimension, constituted and exercised through the rights and obligations of citizens vis-à-vis the state. Third, citizenship has a dimension of practices, articulating political identities, group consciousness and community.

The legislation defining the status of citizenship (nationality laws) has the purpose of ensuring continuity and conditions of membership. It regulates who is entitled to establish the link with the state $a b$ initio, and who and under what conditions may be granted the possibility to establish such a link. In the former case, the entitlement to citizenship is commonly based on descent (ius sanguinis) or in some countries on birth on the country's territory (ius soli) (Aleinikoff and Klusmeyer 2002; Also: Global Citizenship Observatory Databases 2017). In the latter, the possibility for attaining citizenship is based on meeting the conditions that ensure the individual's commitment to the polity, such as residence, income, and acceptance of various symbolic and ideational elements of membership (e.g., flags, anthems, etc.).

Equally, laws defining the exercise and practices of membership regulate the rights and duties of citizenship, which, like the status of citizenship are exclusionary. That is, many of the rights and duties of citizenship become accessible to individuals once they reach a certain age or meet other conditions. Commonly, political rights (e.g., voting rights) are attainable once an individual becomes of age; military duty, where it still 
exists, is commonly related to individuals' age and (male) sex, although there are exceptions to this (e.g., Israel); taxation depends on an individual's economic position in society (e.g., employed/unemployed, possession of property or not, etc.).

The matters related to membership, rights and obligations of citizenship have occupied a central place in the post-communist states, where they have been commonly used as a tool of ethnic majorities to ensure their dominance in the state through the rules for inclusion and exclusion (Štiks 2006, 2016). The uneven distribution of the rights of membership that followed from the diversified citizenship statuses helped to reinforce 'constitutional nationalism' by creating a 'constitutional and legal structure that privileges the members of one ethnically defined nation over other residents in a particular state' (Hayden 1992, 655).

However, the regulation of membership and rights in post-partition federations exhibits a different dynamic due to the interplay between federal citizenship and the citizenship of the sub-federal (and thus ethnically homogeneous) units. The relationship between these two layers of citizenship is best described through the notion of a "citizenship constellation', which Bauböck $(2010,848)$ defined as 'a structure in which individuals are simultaneously linked to several political entities, so that their legal rights and duties are determined not only by one political authority, but by several'. Multilevel polities are examples of a vertical 'citizenship constellation', in which the determination of rights and duties takes place in hierarchically structured levels.

In the federal states created through ethnonational break-up, experiences of vertical citizenship constellations are not only related to their prior membership in multinational federations, but also to the way in which the new state has been conceived. Both in the domain of membership and that of the rights of citizenship, relationships between the federal state and the territorial unit define the rules for inclusion and exclusion. In the case of the post-Yugoslav federal states, while being essentially re-conceived after the state break-up, these relationships have been molded through the experiences of citizenship in the socialist federation, and the way in which state- and nation-building projects gave birth to new states. Continuities with the old federation can best be seen in the initial conception of membership regardless of whether the new federation was created through international intervention or not. However, the way in which these two states have been conceived and the degree of involvement of the international community in this process affected the replications of the old federal structure. 
Continuity regarding the regulation of the status of membership is mirrored in the adoption of the two-tiered citizenship model in both the FRY and BiH. The two-tiered citizenship was, in both cases, conceived through the federal and the sub-federal levels - republican in the FRY and entity in BiH. While in principle the federal citizenship has legal primacy over the republican/entity one, in practice, in both cases the centrifugal tendencies of the sub-units challenge the primacy of the federal regulation of citizenship. A further replication of the old federal structure in both cases is the use of the (secondtier) republican citizenship instead of the zero-option to regulate status in the initial determination of citizenship. The former conferred citizenship of the new state to those in possession of the status of citizenship in one of its constituent republics, while the latter would have included as members those residing in the respective republics at the time of creation of the new state.

Historical institutionalism can help explain this dynamic by emphasizing the importance of historical precedence for future policy directions (Steinmo 2012). Therefore, it is not surprising that the post-Yugoslav federations first looked at the experience and application of citizenship legislation in Yugoslavia, a state in which they were members for forty years and whose diversity and multinationalism shared many of the key features that influenced politics in Bosnia and the FRY. Finally, both the 1996 FRY Citizenship Act and the 1997 Law on Citizenship of BiH were applied retroactively, since the date of creation of the FRY (27 April 1992) and the independence of Bosnia and Herzegovina (6 April 1992). Yet, as a consequence of different modalities of break-up and creation of the new multilevel states, this retroactive application had opposite purposes. In the FRY, it had an exclusionary function because it sought to avoid admittance of the people who sought refuge in Serbia or in Montenegro from the wars of Yugoslav disintegration. In post-war BiH, the retroactive enforcement of citizenship law had the objective of preventing statelessness and enabling the return of refugees.

By contrast, because of different break-up trajectories and different degrees of international involvement in the creation of these two post-partition federal states, on the dimension of the rights and obligations of citizenship, we can see a departure from the socialist Yugoslav model. In BiH, rights were determined by the federal level and implemented by the republics. In the FRY, most of the citizenship rights were indeed determined at the federal level, and all but voting rights could be implemented on the 
whole territory of the state. As will be discussed below, in $\mathrm{BiH}$, the exercise of rights at the federal level is determined through a combination of entity citizenship and ethnic belonging. Such a link between the sources and the distribution of the rights of citizenship is counterintuitive to the logic commonly applied in other federal states. In most federal states, the rights of citizenship are derived both 'top-down' and 'bottom up'. The encompassing polity (i.e. the federation) is the access point for citizenship status and rights, which are then distributed to subnational polities. Some exceptions from this general definition exist, such as those in Austria and Germany, where federal provinces have some discretion in controlling migrants' access to citizenship; or in Switzerland, where cantonal and municipal citizenships give rise to the federal citizenship (Bauböck 2007). Even in these cases, the power of territorial units is derived from legislation at the federal level, unlike in the case of $\mathrm{BiH}$ where the source of status and rights are the entities rather than the federal state.

Such a conception of citizenship, marked with a strong discrepancy between the sources and distribution of citizenship rights, is the product of the interplay of two factors: 1) the war in Bosnia, which introduced ethnically homogenous territorial units as a result of widespread ethnic cleansing (Keil 2013); and 2) engagement of the international actors in constitutionalizing the Bosnian state. The territorialization of ethnicity laid the foundations of Bosnia's current federal political system, and was crucial for the development of its citizenship policies. Yet, the arrangement of relations between these territorial units within this multi-level federation took place in a framework moderated by the international community. Hence, the importance of the ways in which secession occurred and the modalities of creating the new state cannot be overstated. Both constitute critical junctures 'during which there is a substantially heightened probability that agents' choices will affect the outcome of interest' in shaping the governance of citizenship (Capoccia and Keleman 2007, 348, emphasis in original).

\section{The Roots of Continuity and Discontinuity: Citizenship Experience in the Socialist Federation}

Continuity and discontinuity in the citizenship policies of post-partition states requires an understanding of the institutional context that preceded the newly established 
federations. The previous regulatory framework is important not only for ascertaining the persisting legacies in new states, but also for identifying where new policies and institutions replicate centrifugal tensions that existed between the core and the seceding state.

Both BiH and the FRY were constituted through the process of Yugoslav disintegration. Yugoslavia was recreated as a federal state after the Second World War. ${ }^{\text {ii }}$ It consisted of six Republics (Bosnia and Herzegovina, Croatia, Macedonia, Montenegro Serbia, and Slovenia) and two autonomous provinces of Serbia (Kosovo and Vojvodina). ${ }^{\text {iii In }}$ many respects, Yugoslav federalism was unique, as it combined communist rule with genuine decentralization (after 1960) and the relatively far-reaching autonomy of the different sub-units (Dunn 1975; Ramet 1992). The decentralized Yugoslav federation recognized different membership categories, including 'nations', 'nationalities' and 'ethnic groups' (Lendvai and Parcell 1991). These statuses co-existed at the federal and the republican levels, but did not necessarily coincide or overlap. The Yugoslav concept of 'nations' designated the majority ethnic community that inhabited the territory of a particular republic; 'nationalities' included minorities with kin-states outside of Yugoslavia (e.g., Bulgarians, Albanians); while 'ethnic groups' denoted communities without a kin-state. The changing relationships between the republics as territorialpolitical units and the different citizenship statuses were central to the evolution of the different facets of the 'citizenship constellation' of the socialist Yugoslavia.

The 1946 Yugoslav Constitution officially recognized five nations which were also 'titular' for five out of six of its republics - Croats in Croatia; Macedonians in Macedonia; Montenegrins in Montenegro; Serbs in Serbia; and Slovenians in Slovenia. ${ }^{\text {iv }}$ Bosnia and Herzegovina was the only former Yugoslav republic that remained without a titular nation, meaning that Bosnia was the only Republic not associated with one dominant ethnic group. With the constitutional amendments of 1968, Muslims (written with a capital ' $M$ ' to distinguish the ethnic from the religious community) were granted the status of a titular nation at the federal level. However, they did not become a titular nation in any of Yugoslavia's constituent republics, which implied a major discrepancy of status. The federal state was formally constituted by the people (and thus nations, nationalities, etc.), while at the republican level the same federal state was the outcome of the coming together of sub-units 'owned' by their respective ethnic communities. This interplay of state construction and ownership left 
an important legacy on the constitutional setups of the two post-Yugoslav federations. These exhibit continuity when the state was created 'regionally' (by agreement between republics, as was the case in the FRY) and discontinuity, when its creation was mediated 'internationally' (as was the case with $\mathrm{BiH}$ ).

Moreover, statuses and rights of citizenship were subject to continuous redefinition throughout Yugoslavia's existence. From 1945 until its dissolution in 1991, the SFRY adopted four federal citizenship acts $(1945 ; 1950 ; 1964 ; 1976)$, and the respective Republics changed their sub-federal regulation of membership as many times. The evolution of the two-tiers of citizenship regulation in the former Yugoslavia was the outcome of centrifugal tendencies in the country, which had as its result the strengthening of republican citizenship.

The first Citizenship Act was enacted in August 1945, and enforced in July 1946. It determined the conferral of the status of citizenship through territorial and ethnic belonging. The status of federal citizenship had three pillars: 1) continuity with Yugoslav citizenship under the 1928 Citizenship Act for the territories and people this law applied to; 2) 'zero-option' (residence on the territory) for permanent residents of territories added to Yugoslavia after the Second World War (art. 3); 3) ethnicity for those who belonged to the Yugoslav nationalities and had no other citizenship (art. 25). The republican citizenship established by the 1945 Citizenship Act automatically created a vertically nested 'citizenship constellation', because each citizen of the federation was simultaneously a citizen of one of its constituent republics (arts. 28-34). The subsequent republican citizenship acts were virtually identical, and reiterated the federal citizenship provisions. Such a relationship between the federal and the republican citizenship was retained in the federal citizenship acts of 1950 and 1964. The precedence of the federal citizenship was clear, and membership in the constituent republics was conditional upon the status of being a Yugoslav citizen.

These vertically nested 'citizenship constellations' remained tightly coupled until constitutional and socio-political changes took place in Yugoslavia in the mid-1970s (Cohen 1993; Dunn 1975; Štiks 2015). The subsequent strengthening of the republics vis-à-vis the Yugoslav federation was also reflected in the regulation of citizenship. The 1976 Yugoslav Citizenship Act was similar to its three predecessors in terms of the general norms determining and regulating status, such as the dominance of ius sanguinis and the prohibition of dual citizenship among republics. In practice, however, 
the 1976 Yugoslav Citizenship Act significantly loosened the links between the two tiers of citizenship; above all, by establishing the Federal Citizenship Register. Despite its denomination as 'federal', the maintenance of the Citizenship Register was a competence of the authorities of the constituent republics. Hence, the implementation of citizenship rules became practically transferred to the republican level, despite the legal precedence of the federal laws.

This citizenship constellation of the federal Yugoslavia was also loosened through the republican citizenship laws of the 1970s, which 'not only remained in force until the dissolution of Yugoslavia in the early 1990s, but also were significant for the initial determination of citizenry in the new states' (Džankić 2015, 87). Unlike the earlier laws, the new republican citizenship acts were neither adopted simultaneously, nor were they completely identical (Štiks 2015). They did however keep the prohibition of dual citizenship among republics, which had a twofold implication for the states carved out of the socialist federation.

First, republican citizenship acts of the 1970s became key for the realization of voting rights in the federal state. Yugoslavia was not a democratic state and political representation took place through a complex system of delegation, within which individuals exercised voting rights in line with republics' Citizenship Registers, regardless of their residence. For instance, if an individual had Croatian republican citizenship, but lived in Serbia, he or she would be entered in the Croatian Citizenship Register and have voting rights in Croatia. ${ }^{v}$ This implies that 'formal' citizenship of republics was at the core of the Yugoslav federal state. Coupled with the notion of 'titular' nations, this feature of the federal citizenship regime blocked 'zero solutions' in the initial determination of citizenship after the break-up.

Second, while the two-tiered citizenship regime that socialist Yugoslavia applied had in practice very little meaning for ordinary citizens, it became a major tool of inclusion and exclusion at the time of creation of new self-defined nation-states. Unlike the former Soviet Republics, the post-Yugoslav states determined their post-independence membership on grounds of the republics' Registers of Citizens (Štiks 2006). Due to poor administration of such registers, individuals who spent decades in a Republic other than that of their citizenship, were at a high risk of statelessness at the time of the Yugoslav disintegration. Many elements of this legacy can be traced in the regulation 
of citizenship in the FRY, whose final break-up left significant numbers of people in Serbia and in Montenegro without a status of citizenship (Rava 2010).

\section{Fragmentation of Citizenship in the FRY}

Break-ups of multilevel polities may result in federations that persist over time, or they can fragment further into ethnically more homogenous unitary states. The former is the case in $\mathrm{BiH}$, as well as in the multinational federal states that have been created through independence from British colonial rule. The completion of ethnonational break-up, as has happened in the FRY, is more common, certainly within the post-socialist world, where several unrecognized statelets symbolize the demands for recognition and further ethnonational division in countries such as Georgia, Azerbaijan and Moldova (Caspersen 2011). Nonetheless, as the continued discussions over the status of Serbs in North Kosovo, Albanians in North Macedonia or minority rights for Serbs in Croatia indicate, even in cases where the secessionist break-up was along ethnic lines, important issues related to the management of diversity and minorities remain, often leading to new forms of exclusion and discrimination (Štiks 2015).

Paradoxically, the FRY was the only federal state that was established by voluntary agreement between two constituent Republics after the Yugoslav break-up. The constitution of 27 April 1992 set the grounds for the common state between Serbia and Montenegro, the largest and the smallest among the former Yugoslav Republics. The same constitution formally established the category of FRY citizenship, with elements of both continuity and discontinuity with the membership rules in the socialist Yugoslavia. Similar to the old federation, the constellation of citizenship of the FRY consisted of two tiers - the Yugoslav citizenship as membership in the encompassing polity, and the republican citizenship as its sub-federal tier (art. 17).

Citizenship policy remained vague in the initial years of existence of the FRY. The decoupling of the old socialist Yugoslav citizenship and the re-coupling of the citizenship policies of Serbia and Montenegro in a new federation was central to the lack of clarity in defining who 'belongs'. The 1992 constitution stipulated that a separate federal law would be adopted to regulate membership in the newly established state. Nonetheless, such a law was not adopted until mid-1996, which was a clear effect of the wars that followed the Yugoslav break-up in Croatia and BiH. The four-year delay in the 
formulation of citizenship legislation allowed the policy-makers in the FRY a 'greater margin of maneuver when it comes to ethnicity and citizenship, which were particularly malleable at the time of ethnic conflicts' (Džankić 2010, 8). The aim of such a delay was twofold. First, according to Štiks (2006), the deliberate manipulation of citizenship policy supported Milošević’s 'ethnic engineering', a policy through which ethnic Serbs who fled the wars in Croatia and $\mathrm{BiH}$ were resettled in specific geographic locations within the FRY. The objective of such a policy was to increase the number of ethnic Serbs in areas such as Vojvodina, Kosovo, and southern Montenegro, areas of the FRY that were inhabited by ethnic minorities, such as Hungarians, Albanians or Croats. Second, the delay in adopting the citizenship policy of the FRY enabled the country's policymakers to fuel the wartime activities in $\mathrm{BiH}$ by providing manpower to the Army of the Republika Srpska in BiH. This was done by forcible mobilization by the FRY authorities of the male refugees from Croatia and Bosnia and Herzegovina (European Civic Forum 1994).

The 'citizenship constellation' between Serbia and Montenegro was finally defined through a federal citizenship law in 1996. The federal citizenship had absolute legal primacy over the republican level, a path dependency from socialist legislation. However, the definition of the 'people' was based on republican laws from the 1970s, which points to a discrepancy in the construction of membership. As mentioned previously, the 1996 federal citizenship law was applied retroactively. At the same time, membership in the federal state was determined on grounds of the registered republican citizenship of Serbia and of Montenegro. In addition to exposing a number of intraYugoslav migrants to the risk of statelessness (Krasniqi and Stjepanović 2015; Djordjevic 2015), the reliance on the imperfect republican-level citizenship registers for the construction of membership in the new federation created a mismatch between the individuals who actually resided in the FRY territory and those who were formally registered as its citizens. This clash of different citizenship legislation frameworks was to become a key feature in the relationship between the FRY as the core, and Serbia and Montenegro as its constituents.

The discontinuity of the FRY citizenship regime with the Socialist Yugoslav one was reinforced by the change of political dynamics between the two constituent republics. By the time the 1996 Yugoslav Citizenship Act entered into force, the Montenegrin ruling elite started to detach from Milošević's politics, and to gradually move towards 
independence. This significantly altered the relationship between the federal citizenship as the citizenship of the encompassing policy and the citizenship of one of the constituent parts of the FRY. At the same time, the citizenship regulation of Serbia remained in line with the federal citizenship regulation.

The Law on Montenegrin Citizenship, enacted on 1 November 1999, is a clear example of how legislative measures were used to detach competences from the federal level and how citizenship policies were pivotal for the arithmetic of voting. Even though federal citizenship policy had legal primacy, the 1999 Law on Montenegrin Citizenship allowed the acquisition of republican citizenship without the prior or simultaneous acquisition of the federal one. Since the federal legislation did not provide for the possibility of membership in a sub-federal unit without federal membership, the laws were clearly in conflict. The FRY authorities, however, did not exclude individuals who obtained the citizenship of Montenegro in line with the 1999 Law on Montenegrin Citizenship. Since membership in the federation was constituted by membership in the constituent republics, the adoption of this law had a paradoxical effect. Despite the decoupling of Montenegrin citizenship from the federal level, from the perspective of the FRY, the two remained tightly coupled.

The cutout of Montenegro's citizenship policy had a dual function. First, it was used as a mechanism of nation-building by focusing on Montenegrin as a distinct and separate identity from the Serbian one (Morisson 2009; Džankić 2014). Second, it became a tool for state-building, by means of undermining the authority of the FRY and seeking conflict with both Serbia and the FRY to enhance the autonomy and competences of Montenegrin institutions.

The transformation of the FRY into the State Union of Serbia and Montenegro in 2003 abolished the second Yugoslav federation, marking a further discontinuity from the federal model of the former Yugoslavia. Above all, citizenship of the State Union of Serbia and Montenegro, loosely based on the EU citizenship model where membership in the encompassing polity is conditional upon membership in the national polities, was never formally constituted. Rather, Article 7 of the Constitutional Charter stipulated that 'A citizen of the constituent state is a citizen of Serbia and Montenegro', but never contained a provision such as 'Citizenship of the Union is hereby established' (article 20, Treaty on the Functioning of the European Union). 
The transformation of the common state triggered a further discontinuity in terms of coherence of applicable legislation. Until 2004, the 1996 FRY citizenship law was still implemented in Serbia, along with the 1976 Serbian Citizenship Act. In Montenegro, the federal citizenship legislation ceased to have effect with the entry into force of the 1999 Montenegrin Citizenship Act. In 2004, however, Serbia changed its citizenship law, guaranteeing legal continuity of Serbian citizenship within the new State Union with that of the FRY (Rava 2010). With the adoption of the 2004 Serbian citizenship legislation, the 1996 FRY Citizenship Law ceased to be implemented in both members of the State Union. Hence formally, until its dissolution in June 2006, Serbia and Montenegro had their own citizenship regimes, while the State Union citizenship was virtually non-existent.

The relationship between the federal and the republican citizenships in the FRY and Serbia and Montenegro is indicative of how political developments can shape and transform the notion of membership in territories where the multilevel state is fragile. Originally, the FRY was a tightly coupled federation, in which the political and legislative processes at the federal and republican levels converged. The protraction in the adoption of the federal citizenship legislation was therefore not an illustration of the competition between the two levels of polity. Rather, it has been an indicator of the high degree of their nestedness. The divergence in the political course of Montenegro, and its gradual detachment from the federal institutions, reveals how centrifugal tendencies in the subnational citizenship can be used as a form of resistance to the centralizing forces at the federal level. Equally, the departure of Montenegro from the FRY citizenship model has revealed the centrality of discontinuities, fragmentation and membership paradoxes that emerge when post-partition federations become unsustainable.

\section{Keeping it All Together: Imposition and Ethnic Exclusion in Bosnian}

\section{Citizenship}

Bosnia and Herzegovina was formed as a federal country in 1995, as a result of the Dayton Peace Agreement (DPA), which ended the 3.5-year long war in the country. Bosnia's system has been characterized as one of 'imposed federalism', introduced by 
international actors to end the conflict and protect the territorial integrity of the country (Keil 2013, 131). Unlike the FRY, the different territories in Bosnia (entities and cantons) did not come together voluntarily, but were the result of different conflicts, ethnic cleansing campaigns and international intervention in Bosnia (Keil 2012). ${ }^{\text {vi }}$ The war was characterized by centrifugal tendencies and the aims of Croat and Serb elites in Bosnia were to divide the country and unite territory under their control with the respective kin-states. This background is important, because it continues to influence post-war discussions in the country and significantly shapes the federal elements of the country's citizenship regime (Keil and Perry 2015).

Bosnia's Constitution, adopted as Annex IV of the DPA, ascertains the existence of a Bosnian citizenship. In December 1997, a new law on citizenship established a first legal framework for citizenship in the post-war country, and the 1999 the Law on Citizenship of Bosnia and Herzegovina which provided a more comprehensive set of regulations on the acquisition and loss of citizenship. Similar to the case of the FRY, the citizenship legislation was applied retrospectively. The logic of the retrospective provision in Bosnia was however different for the initial determination of citizenry from that of the FRY. In the latter case, it was a mechanism of exclusion of those who sought refuge in Serbia and Montenegro. In Bosnia, granting citizenship to all those who had been included in the republican registry of citizens in 1992 was done to (1) ensure that refugees who had left the country during the war could return and claim citizenship rights, as well as (2) an attempt to undo the consequences of the ethnic cleansing. Citizens were allowed, and after 1999 strongly encouraged by the international community, to return to their pre-war homes, claim any lost property and exercise their citizenship rights (Sarajlić 2010). While this policy has had some success, overall, Bosnia remains an ethnically divided society, in which the majority of territory is dominated and controlled by one of the three constituent peoples (Bosniaks, Serbs and Croats) (Toal and Dahlmann 2011).

Beyond this issue of the initial determination of citizenry, the structure of the current citizenship regime of Bosnia and Herzegovina is complicated and, in many respects, unique (Sarajlić 2010). The clearest continuity with the citizenship regime of the socialist Yugoslavia is the two-tiered citizenship model. The continuity of the substance of the relationship between the federal and subnational citizenships is far less so. Article I.7 (e) of the Bosnian Constitution states that the entities and the institutions of Bosnia and Herzegovina can award Bosnian citizenship. The Constitution also outlines that the 
citizenship of Bosnia and Herzegovina is linked to citizenship of one of the entities. Yet this link remains unclear, as neither the Constitution nor the 1999 Law on Citizenship of Bosnia and Herzegovina establish clear primacy of either federal or entity legislation. No legal provision in the Bosnian legislation conditions the status of a citizen of Bosnia and Herzegovina on a prior status of an entity citizen, but article 27 of the 1999 Law does so indirectly by a loss clause: losing entity citizenship would lead to an automatic loss of the citizenship of Bosnia and Herzegovina. In this context, the precedence of federal over entity citizenship would be a clear indicator of continuity with the citizenship policies of the socialist Yugoslavia, while primacy of subnational legislation would point to a strong discontinuity.

In practice, entities administer and have the final say in awarding (and revoking) citizenship. The contents of the entity citizenship laws resemble those of independent states, but in most aspects are aligned with the 1999 Law. As a result, Bosnia's system has been characterized as a form of fractured citizenship, where the 'the state citizenship of Bosnia and Herzegovina is largely emblematic, [and] those of the entities are the ones that are administratively functional' (Džankić 2015, 75). This is significant, because the entities continue to define themselves in ethnic terms, despite efforts to counterbalance this. The Constitutional Court ruling of July 2000 (U-5/98), for instance, stipulated that 'territorial division cannot serve as a constitutional legitimacy for ethnic domination, national homogenisation or the right to maintain results of ethnic cleansing'. The subsequent changes to the entity constitutions prevented the $\mathrm{FBiH}$ and the RS from referring to selected ethnic groups as their main inhabitants (i.e. RS as the state of Serbs in Bosnia). However, day-to-day political practice highlights the importance of ethnicity in the citizenship constellation of Bosnia and Herzegovina. This was of special relevance in the immediate post-war years, when ethnic engineering and practical political and societal pressure played a key part in ensuring that different territories in Bosnia remained populated nearly exclusively by one group.

Having in mind that the Bosnian citizenship regime, heavily influenced by the international factors, was adopted against a backdrop of a major ethno-territorial conflict, it has had uneven effects on citizenship rights of the different groups. That is, holding Bosnian citizenship does not mean the same rights for all Bosnian citizens and ethnic criteria play an important role in the composition of Bosnia's institutions. For example, only members of the three constituent peoples - Bosniaks, Croats and Serbs - can become members of Bosnia's Presidency and the House of Peoples at the federal 
level, which is exclusionary towards minority ethnic communities. In the Sejdić and Finci vs. Bosnia and Herzegovina (27996/06 and 34836/06) judgment, the European Court of Human Rights (ECtHR) ruled that constitutional provisions precluding nonconstituent peoples from exercising citizenship rights are a form of discrimination and that as such they constitute a violation of European Convention of Human Rights (ECtHR 2009). Implementing the Court's judgement requires constitutional amendments, which would entail a restructuring of the power-sharing arrangements and new power balances 1) among the constituent peoples and 2) between constituent peoples and those who do not belong to them. As a result, constitutional reform has been in a deadlock for over a decade now (Stojanović and Hodžić 2015), in spite of further judgements of the ECtHR on similar cases and substantive efforts by the European Union (EU) and the Venice Commission of the Council of Europe.

Finally, similar to the citizenship regime of the former Yugoslavia, that of Bosnia and Herzegovina is characterized by strong centrifugal tendencies, particularly as regards the symbolic and ideational elements. Yet far stronger than in the SFRY, symbols highlight the lack of common bond among Bosnia's constituent peoples, and demonstrate an intense affiliation of ethnic communities with their neighbouring kin states. For example, the use of the Cyrillic alphabet continues to be dominant and exclusive in many parts of the RS, despite the abovementioned Constitutional Court ruling of July 2000 (U-5/98), which has ordered the RS to make all three languages (Bosnian, Croatian and Serbian) official. In the RS, the use of the Serbian flag is widespread, while the Croat flag is visible all across the Croat cantons. Holding a dual nationality of Serbia or Croatia is tolerated in Bosnia and Herzegovina yet not explicitly allowed. Hence, obtaining a passport of Serbia or Croatia through ancestry or kinship is a symbolic gesture at the individual level. Yet, is a major indicator of the disjointed nature of Bosnia's citizenship and a lack of political and social integration of the country.

\section{Conclusion}

While the incomplete ethnonational break-ups presented in the two cases in this paper are rare, they nevertheless tell us some wider stories about the trajectories of citizenship in post-secession territories. The cases of the FRY and BiH indicate that the interplay 
between institutional legacies and replicated federal structures can have different outcomes in cases of 'voluntary' and 'involuntary' post-partition federations, and how they can break states apart or join their constituents together. Our analysis shows how citizenship regimes in countries that have seceded from federal and other multi-level systems will engage in complex formulations of their citizenship regimes. These processes will include a mix of historical continuities- i.e. incorporating elements of the previous federal/multi-level citizen regime and connecting it with new elements of ethnic engineering and state-building. Similar trajectories can be observed in other secessionist territories as well (Arrighi and Stjepanović 2019; Bauböck 2019; Caspersen, 2011, 76-101; Malyarenko and Wolff 2019, 30-43; Owtram, 2019).

Our case study of the FRY and BiH has first highlighted that the heritage of the 'mother' state has an important role in constituting the new polity at the time of independence. Newly established states followed many of the political and legal frameworks provided by the SFRY in the design of their own citizenship legislation. We can therefore identify a number of historical continuities, such as the vertical citizenship constellation that both the FRY and $\mathrm{BiH}$ adopted, as well as the continued interplay of territorial unit and federal citizenship provisions in terms of legal framework and implementation obligations. However, there are also a number of important differences, such as the much stricter focus on who belongs to the state (exemplified by the FRY law of 1996) and who has which rights in which territory of the country (as demonstrated in the direct and indirect voting rights in Bosnia). This points to the conclusion that while historical legacies matter, critical junctures decisively affects the regulation of important policy fields such as citizenship legislation.

Both successor federations of the SFRY have used a two-tier citizenship framework in order to organize citizenship. Nonetheless, while the SFRY had a relatively clear and coherent framework (at least until 1970), the same cannot be said for its successor states. The FRY waited until 1996, before it implemented a law, and after 1997 Montenegro began to divert from this joint legislation. This eventually resulted in a separate Montenegrin Law in 1999, which contradicted the federal citizenship legislation. Here, the attempts of defining the nation are clearly visible, both in the strict rules of the 1996 FRY act, and in the 1999 Montenegrin Citizenship Act, which also focused on laying the groundwork of an independent Montenegrin identity (and state). Likewise, the citizenship provisions in Bosnia do not clearly define who can award citizenship and 
which rights and obligations are connected to it. While the entities play a major role, according to the constitution, the institutions of Bosnia and Herzegovina can also award Bosnian citizenship. It is not clear how this provision would link Bosnian and entity citizenship, or which Bosnian institutions could award citizenship. Additionally, Bosnia's provisions exclude certain members of the population (including those having Bosnian citizenship) from active and passive voting rights, because these are connected to self-identification with one of the three constituent peoples. The above-mentioned focus on nation-building and creating ethnically homogenous entities (and cantons) is visible in these provisions. In both cases, radical breaks with the past can be observed in light of ethnic conflict and secession. However, historical legacies and continuities are very much visible in institutional and policy choices, even if re-framed by wars, and nation- and state-building processes. This is clearly the case in the FRY, but also to an important degree in Bosnia, a country that saw its post-war institutional framework mainly written by external actors.

The two post-partition federations studied in this paper show how fragile the social contract can be in multilevel states that struggle to accommodate diversity. Such states might effectively be formally constituted as federal, at least in terms of the normative dimension of federalism (Burgess 2012). Yet they may display no commitment to federal values. If the core question of 'who belongs' remains unanswered and if there is disagreement over who defines the state and how, citizenship policies can serve different purposes. They can be the tools that ultimately dismantle the fragile state, or they can become the glue that can keep even a dysfunctional state in one piece. In this regard, citizenship design is an important element in federal state-building. Historical continuities and critical junctures in the choice of citizenship policy frameworks tell us a wider story about membership not only in post-secession territories and states, but also in other post-conflict federations that struggle with finding the right balance between accommodating diversity and keeping the state together. Trajectories and pathways that the cases of FRY and BiH have revealed, could serve as useful analytical lenses for other new federal models that have evolved out of ethnic conflict, such as Ethiopia, Iraq or Nepal. 


\section{Bibliography}

Aleinikoff, T. A., \& Klusmeyer, D. (Eds.). (2012): Citizenship policies for an age of migration. Carnegie Endowment.

Aron, R. and Hofstadter, D. (1974): Is Multinational Citizenship Possible? in: Social Research, Vol. 41, No.4, 638-546.

Arrighi, J. T., \& Stjepanović, D. (2019). Introduction: The rescaling of territory and citizenship in Europe. Ethnopolitics, 18(3), 219-226.

Bauböck, R. (2007): Political boundaries in a multilevel democracy. In Seyla Benhabib \& Ian Shapiro (eds.), Identities, Affiliations and Allegiances. Cambridge University Press. pp. 85-112

Bauböck, R. (2010): Studying citizenship constellations. Journal of ethnic and migration studies, 36(5), 847-859.

Bauböck, R. (2019). A multilevel theory of democratic secession. Ethnopolitics, Vol 18(3), 227-246.

Bellamy, R., Castiglione, D., \& Santoro, E. (2004): Lineages of European citizenship: rights, belonging and participation in eleven nation-states. Springer.

Bieber, F. (2006): Post-War Bosnia: Ethnicity, Inequality and Public Sector Governance, Basingstoke and New York: Palgrave MacMillian.

Brubaker, R. (1996): Nationalism reframed: Nationhood and the national question in the new Europe. Cambridge University Press.

Burgess, M.: In Search of the Federal Spirit - New Theoretical and Empirical Perspectives in Comparative Federalism, Oxford and New York: Oxford University Press.

Burgess, M. (2006): Comparative Federalism - Theory and Practice, London and New York: Routledge.

Capoccia, G. and Kelemen, R.D. (2007): The Study of Critical Junctures: Theory, Narrative, and Counterfactuals in Historical Materialism. World Politics, 59(3), 341369.

Caspersen, N. (2011): Unrecognized States: The Struggle for Sovereignty in the Modern International System. London: Polity Press. 
Choudhry, S. (2001): Citizenship and Federations: Some Preliminary Reflections, In: K. Nicolaidis and R. Howse, (Eds.) The Federal Vision: Legitimacy and Levels of Governance in the US and the EU, K. Nicolaidis and R. Howse, eds., Oxford: Oxford University Press, 377-402.

Cohen, L. J. (1993): Broken bonds: the disintegration of Yugoslavia. Westview Pr.

Dunn, W.N. (1975): Communal Federalism: Dialectics of Decentralization in Socialist Yugoslavia' in: Publius- The Journal of Federalism, Vol. 5, No. 2, pp. 127150.

Džankić, J. (2010): Transformations of Citizenship in Montenegro: a contextgenerated evolution of citizenship policies. CITSEE Working Paper 2010/03. University of Edinburgh

Džankić, J. (2012): Understanding Montenegrin citizenship. Citizenship Studies, 16(3-4), 337-351.

Džankić, J. (2015): Citizenship in Bosnia and Herzegovina, Macedonia and Montenegro: effects of statehood and identity challenges. Ashgate Publishing, Ltd. Elazar, D. (1982): Exploring Federalism, Tuscaloosa: The University of Alabama Press.

Ferrera, M (2003): European Integration and National Social Citizenship: Changing Boundaries, New Structuring?. Comparative Political Studies, 36(6), 611-652.

Forsyth, M. (1981): Union of States: The Theory and Practice of Confederation, Leicester: Leicester University Press.

Grgić, G. (2017). Ethnic Conflict in Asymmetric Federations - Comparative Experience of the Former Soviet and Yugoslav Regions. London and New York: Routledge.

Hayden, R. M. (1992): Constitutional nationalism in the formerly Yugoslav republics. Slavic review, 51(4), 654-673.

Heinemann-Grüder, A. (Ed.): Federalism Doomed? European Federalism between Integration and Separation. New York and Oxford: Berghahn Books.

Horowitz, D. (2003): The Cracked Foundations of the Right to Secede. Journal of Democracy, 14, 5-17. 
Jackson, V. (2001): Citizenship and Federalism. In: Alleinikoff, A. and Klusmeyer, D. (Eds.). Citizenship Today - Global Perspectives and Practices. Washington D.C. Carnegie Endowment for International Peace, 127-183.

Joppke, C. (2003): Citizenship between de-and re-ethnicization. European Journal of Sociology/Archives Européennes de Sociologie, 44(3), 429-458.

Joppke, C. (2007): Transformation of citizenship: status, rights, identity. Citizenship studies, 11(1), 37-48.

Keil, S. (2013): Multinational Federalism in Bosnia and Herzegovina, Abingdon and Burlington: Ashgate.

Keil, S. (2012): Federalism as a Tool of Conflict Resolution: The Case of Bosnia and Herzegovina, in: L'Europe en Formation, Vol. 54, 205-218.

Keil, S. and Perry, V. (2015): State-Building and Democratization in Bosnia and Herzegovina, Abington and Burlington: Ashgate.

Kincaid, J. (1999) Confederal federalism and citizen representation in the European Union, West European Politics, 22(2,) 34-58

Lendvai, P., \& Parcell, L. (1991). Yugoslavia without yugoslavs: the roots of the crisis. International Affairs (Royal Institute of International Affairs 1944-), 251-261.

Linklater, A. (1996): Citizenship and sovereignty in the post-Westphalian state. European Journal of International Relations, 2(1), 77-103.

Malyarenk, T. and Wolff, S. The Dynamics of Emerging De-Facto States - Eastern Ukraine in the Post-Soviet Space. London and New York: Routledge.

Maas, W. (Ed.) (2013): Multilevel Citizenship, University of Pennsylvania Press: Philadelphia.

Miller, D. (2000): Citizenship and national identity (pp. 125-142). Polity: Cambridge. Morrison, K. (2009): Montenegro. A Modern History, London/New York, IB Tauris. Norman, W. (2006): Negotiating Nationalism: Nation-Building, Federalism, and Secession in the Multinational State, Oxford and New York: Oxford University Press. Owtran, F. (2019). From Shotgun Marriage to Amicable Divorce? The Kurdistan Region of Iraq: Self-Determination, Secession and Recognition in Comparative 
Perspective. In: A. Danilovich (Ed.): Federalism, Secession, and International Recognition Regime - Iraqi Kurdistan. London and New York: Routledge, 72-89. Pierson, P. (1993): When Effect Becomes Cause: Policy Feedback and Political Change. World Politics, 45(4), 595-628.

Ramet, S. P. (1992) Nationalism and Federalism in Yugoslavia 1962-1991, Bloomington: Indiana University Press.

Rava, N. (2010): Serbia: elusive citizenship in an elusive nation-state. CITSEE Working Paper 2010/08. University of Edinburgh

Requejo, F. (2005): Multinational Federalism and Value Pluralism: The Spanish Case, Abindon and New York: Routledge.

Requejo, F. (1999): Cultural Pluralism, Nationalism and Federalism: A Revision of Democratic Citizenship in Plurinational States, in: European Journal of Political Research, Vol. 35, 255-286.

Riker, W. (1964): Federalism: Origin, Operation, Significance, Boston: Little, Brown and Company.

Rosen, M. (2002). Extraterritoriality and Political Heterogeneity in American Federalism. University of Pennsylvania Law Review, 150(3), 855-972

Schmid, S. D., Piccoli, L., \& Arrighi, J. T. (2019). Non-universal suffrage: measuring electoral inclusion in contemporary democracies. European political science, 18(4), 695-713.

Schuck, P. (2000): Citizenship in Federal Systems, in: The American Journal of Comparative Law, Vol. 48, No. 2, 195-226. Shaw, J. and Štiks, I. (2010): The Europeanisation of Citizenship in the Successor States of the Former Yugoslavia: An Introduction, CITSEE Working Paper 2010/01, Edinburgh.

Steinmo, S. (2012): Historical Institutionalism. In: Della Porta, D. and Keating, M. (Eds.): Approaches and Methodologies in the Social Sciences: A Pluralist Perspective. Cambridge and New York: Cambridge University Press, 118-138.

Štiks, I. (2015): Nations and Citizens in Yugoslavia and the Post-Yugoslav States, Bloomsbury: London and New York. 
Štiks, I. (2006): Nationality and Citizenship in the Former Yugoslavia: From

Disintegration to European Integration, in: Southeast European and Black Sea

Studies, Vol. 6, 483-500.

Stojanović, N., \& Hodžić, E. (2015): Introduction: Ethnocracy at the Heart of Europe. Ethnopolitics, Vol. 14(4), 382-389.

Thelen, K. (1999): Historical Institutionalism in Comparative Politics. Annual Review of Political Science, Vol. 2, 369-404.

Toal, G. And Dahlmann, C. (2011): Bosnia Remade - Ethnic Cleansing and Its

Reversal, Oxford and New York: Oxford University Press.

Verdery, K. (1998): Transnationalism, nationalism, citizenship, and property: Eastern

Europe since 1989. American ethnologist, 25(2), 291-306.

Watts, R. (1999): Comparing Federal Systems, $2^{\text {nd }}$ edition, Kingston and Montreal:

McGill Queen's University Press.

Wheare, K. (1964): Federal Government, $4^{\text {th }}$ edition, New York: Oxford University Press.

\footnotetext{
${ }^{\mathrm{i}}$ Historical institutionalism is an approach in the study of politics, which assesses the decisions and non-decisions of certain actors, and their consequences in a historical perspective. It is argued that historical context is important to understand decisions, actors furthermore "learn" from history and historical decisions lead to certain expectations of actors (Pierson 1993, Thelen 1999; Steinmo 2012). Historical institutionalists argue that change happens slowly and evolves over time, but that in certain situations of crises, so called critical junctures, substantial policy and institutional change is possible, which has long-lasting effects (Capoccia and Kelemen 2007).

${ }^{i i}$ From its establishment in 1918 until the Second World War, Yugoslavia was a unitary country.

iii Kosovo only became an autonomous province in 1963, before that it had the status of an autonomous district, which meant less autonomous powers than Vojvodina.

${ }^{\text {iv }}$ By recognising Montenegro and Macedonia the 1946 Yugoslav Constitution went already further than the previous Constitution of Royal Yugoslavia, which only recognised Serbs, Croats and Slovenes.

${ }^{\mathrm{v}}$ Intra-republic migration was common in the former Yugoslavia.

${ }^{v i}$ Bosnia and Herzegovina consists of two entities, the Republika Sprska (RS), which is mainly inhabited by Serbs, and the Federation of Bosnia and Herzegovina (FBiH), which is mainly inhabited by Bosniaks and Croats. The $\mathrm{FBiH}$ is further divided in ten cantons, five with a Bosniak majority, three with a Croat majority and two mixed cantons. For more on the organisation of the political system see Keil 2013, 95-124, Bieber 2006.
} 